\title{
A New Composition of High Heat General Purpose Polystyrene (High Heat GPPS) Resin
}

\author{
K C Basavaraju ${ }^{1 *}$, Darshan Jayanna ${ }^{1}$, Subodh Kumar Pal ${ }^{1}$, Roshan Jha ${ }^{1}$ and Bander Al Farhood ${ }^{2}$ \\ ${ }^{1}$ PETCHEM Department, SABIC Technology Center, India \\ ${ }^{2}$ PETCHEM, SABIC, Riyadh, Saudi Arabia
}

Submission: February 15, 2021; Published: March 22, 2021

*Corresponding author: Basavaraju KC, PETCHEM Department, SABIC Technology Center, Bengaluru, India

\begin{abstract}
A new composition of high heat general-purpose polystyrene (High heat GPPS) resin synthesis is discussed. The new composition of resin involves addition of cross-linker/comonomer in very low concentration during synthesis process. Commercially available vinyl cross-linkers like divinylbenzene (DVB), Ethylene dimethacrylate (EDM), Tricycle (5.2.1.02,6) decanedimethanol diacrylate (TDDDA), Dicyclopentadiene (DCPD) and vinyl comonomer like maleic anhydride, $\alpha$-methylstyrene have been evaluated via bulk polymerization method. DVB showed enhancement in the heat distortion temperature (HDT), vicat softening temperature (VST) \& melt flow index (MFI) compared to the benchmark grade of GPPS, whereas other mechanical and impact properties remained same or better than benchmark grade under identical methods of measurement.

Keywords: Divinylbenzene; Cross-linked; Branching; Polymerization; Heat Distortion Temperature (HDT); Melt Flow Index (MFI)

Abbrevations: HDT: Heat Distortion Temperature; MFI: Melt Flow Index; DVB: Divinylbenzene; EDM: Ethylene Dimethacrylate; TDDDA: Tricycle (5.2.1.02,6) Decanedimethanol Diacrylate; DCPD: Dicyclopentadiene; VST: Vicat Softening Temperature; High Heat GPPS: High Heat GeneralPurpose Polystyrene
\end{abstract}

\section{Introduction}

Polystyrene (PS) is a multipurpose polymer used in varied applications in rigid and foamed forms. Based on orientation of phenyl group on the polymer backbone, polystyrene can be classified into isotactic, syndiotactic and atactic. Isotactic or syndiotactic polystyrene prepared by metallocene catalyst can give HDT/VST around $250{ }^{\circ} \mathrm{C}$ and shows lowest specific gravity compared to any other engineering plastics in the market [1]. XAREC is world's first syndiotactic polystyrene commercialized by Idemitsu Corporation, used in electronic component molding [2]. The first two are commercially not important due to complexity in the synthesis and processability compared to atactic polystyrene. Atactic polystyrene is known as generalpurpose polystyrene (GPPS). It is produced by simple thermal initiated radical bulk polymerization [3]. GPPS is clear, hard and can be used in packaging, household items, and electronics. The excellent physical and processing properties make GPPS suitable for many applications as compared to any other plastics, but its glass transition temperature $(\mathrm{Tg})$ is only $100{ }^{\circ} \mathrm{C}$ that leads to limit its use in certain applications. $\mathrm{Tg}$ dictates the continuous service temperature that is a very important factor for polymer to evaluate its processing and application performance. Therefore, there is a demand for high Tg GPPS. Some efforts have been reported in this direction by copolymerizing styrene with maleimide and imide, which act as hydrogen-bond interaction site in the copolymer [4]. Although there is no direct relation between Tg and HDT in polymers, but in amorphous polymer like GPPS, HDT is close to $\operatorname{Tg}[5]$.

HDT can be improved by increasing the interaction of chains or by restricting the chain mobility at elevated temperature. Although GPPS synthesis process is well established and matured, the market requirement and customer application always demand to develop new process or improve the efficiency of the process. Vinyl based anhydrides, amides, maleimides and methylstyrenes have been explored as comonomers in different loading to enhance the heat resistance of polystyrene [4-5]. This is generally achieved by introducing heteroatom containing monomer in the polystyrene chain, which leads chemical irregularity or steric hindrance in the polystyrene chain. GPPS has been widely used in food packaging containers, disposable containers, kitchenware \& cutleries owing to its excellent transparency, water resistance and colorability. Molded articles prepared by GPPS with lower HDT/VST can undergo structural deformation especially when 
they are used in hot filled applications and lower HDT can affect the production rate during molding due to the long cycle time. Good thermal properties like higher HDT/VST along with flow are important requirement for the product performance with better heat stability \& shorter cycle time in the production line. Therefore, our research was focused in first instant to increase the $\mathrm{Tg}$ and HDT/VST, without affecting flow properties.

\section{Experimental Section}

\section{Material and Methods}

All the chemicals that were used in the process procured from Sigma-Aldrich and used as such.

\section{Gel-permeation chromatography (GPC)}

The molecular weight of intermediate samples and final polymer was measured by GPC at $40{ }^{\circ} \mathrm{C}$ (Make-Shimadzu, Class-VP). THF was used as mobile and diluent solvent, sample concentration $2 \mathrm{mg} / \mathrm{ml}$, column specification- PLgel $5 \mu \mathrm{m}$ MIXED-C, 300 x 7.5 mm, Detector- UV @254nm, standardsMonodispersed polystyrene standards.

\section{Differential scanning calorimetry (DSC)}

Differential scanning calorimetry (DSC) of the samples was done with TA Instruments/DSC Q 1000 by heating the samples from room temperature to $160{ }^{\circ} \mathrm{C}$ and heating rate always maintained at $10 \stackrel{\circ}{\circ} / / m i n$ in nitrogen atmosphere.

\section{High performance liquid chromatography (HPLC)}

Unreacted residual styrene monomer was detected and quantified by high performance liquid chromatography (HPLC) Agilent HPLC-1260 series. The chromatographic condition are as

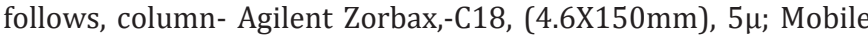
phase: Reservoir A $-0.02 \%$ Orth phosphoric acid in Milli-Q water, Reservoir B-Methanol, Reservoir C - Acetonitrile at different gradients. Flow rate $1 \mathrm{ml} / \mathrm{min}$, detector-diode array detector, wave lenth-254 nm. Column temperatue- $40{ }^{\circ} \mathrm{C}$

\section{Melt flow index (MFI)}

Melt flow index was measured at $230{ }^{\circ} \mathrm{C} \& 2.16 \mathrm{~kg}$ load as per the ASTM D 1238, in GOTTFERT MFI machine (model-MI-4).

\section{Heat distortion temperature (HDT)}

Heat distortion temperature was measured as per the ASTM D648, method B at $0.45 \mathrm{MPa}$ load, on the CEAST machine. All the samples were annealed for $70 \mathrm{hrs}$. at $70^{\circ} \mathrm{C}$ prior to test.

\section{Vicat softening temperature (VST)}

Vicat softening temperature was also measured in CEAST machine for annealed samples as per ASTM D1525. All the samples were annealed for $70 \mathrm{hrs}$. at $70{ }^{\circ} \mathrm{C}$ prior to test.

\section{Mechanical property (Tensile and Izod Impact notched)}

Injection molded specimens are conditioned for $48 \mathrm{~h}$ at $23^{\circ} \mathrm{C}$ $\&$ relative humidity at $50 \%$. Tensile strength was measured were accordance to ASTM D638, on Zwick 2.5 RTI-UTM machine. Izod impact notched was measured as per the ASTM D256.

\section{Polymerization and Processing}

\section{Comonomer/cross linker screening}

The following comonomers/cross linkers were screened in $100 \mathrm{~g}$ batch scale, the concentration of comonomer was maintained at 0-5 wt. \%.<smiles>C=Cc1ccccc1</smiles>

Styrene<smiles>C=Cc1ccc(C=C)cc1</smiles>

Divinylbenzene<smiles>C=C(C)c1ccccc1</smiles>

alpha-methylstyrene<smiles>O=C1C=CC(=O)O1</smiles>

Maleicanhydride<smiles>C1=CC2C3C=CC(C3)C2C1</smiles>

Dicyclopentadiene 
Styrene with comonomer was transferred to the pre-heated $\left(128{ }^{\circ} \mathrm{C}\right)$ glass reactor, the residence time/reaction time and temperature were increased at four different time intervals to make a continuous process. Intermediate samples were collected to monitor molecular weight, $\mathrm{Tg}$ and conversions at every $1 \mathrm{~h}$ interval. Unreacted styrene monomer or residual monomer was removed by precipitating polymer solution (in THF) in hexane and then measured $\mathrm{Tg}$.

\section{Scale-up (1kg) in lab glass reactor setup}

Following three formulation were shortlisted for scale-up in $1 \mathrm{~kg}$ scale in the lab glass reactor setup (Figure $1 \mathrm{SI}$ ) based on the screening experimental results and evaluated thermal, flow \& mechanical properties. The reaction conditions were kept as in Table 1 . The unreacted styrene was removed by applying high vacuum (0-30 mbar) for 10-12 $\mathrm{min}$ at the end of the polymerization.
a. High molecular weight GPPS ( $\left.\mathrm{Mw}>300 \mathrm{~kg} \mathrm{~mol}^{-1}\right)$
b. Evaluation of cross linker DVB at 100 ppm loading
c. Evaluation of comonomer MA at 5 wt. \% loading

Table 1: Residential time and temperature profile in batch glass reactor setup.

\begin{tabular}{|c|c|c|c|c|c|}
\hline & Pre-poly & Step 1 & Step 2 & Step 3 & Step 4 \\
\hline Rx time in h & 2.5 & 0.7 & 0.7 & 0.7 & 0.7 \\
\hline Temp. in ${ }^{\circ} \mathrm{C}$ & 128 & $142-143$ & $146-149$ & $153-156$ & $161-164$ \\
\hline
\end{tabular}

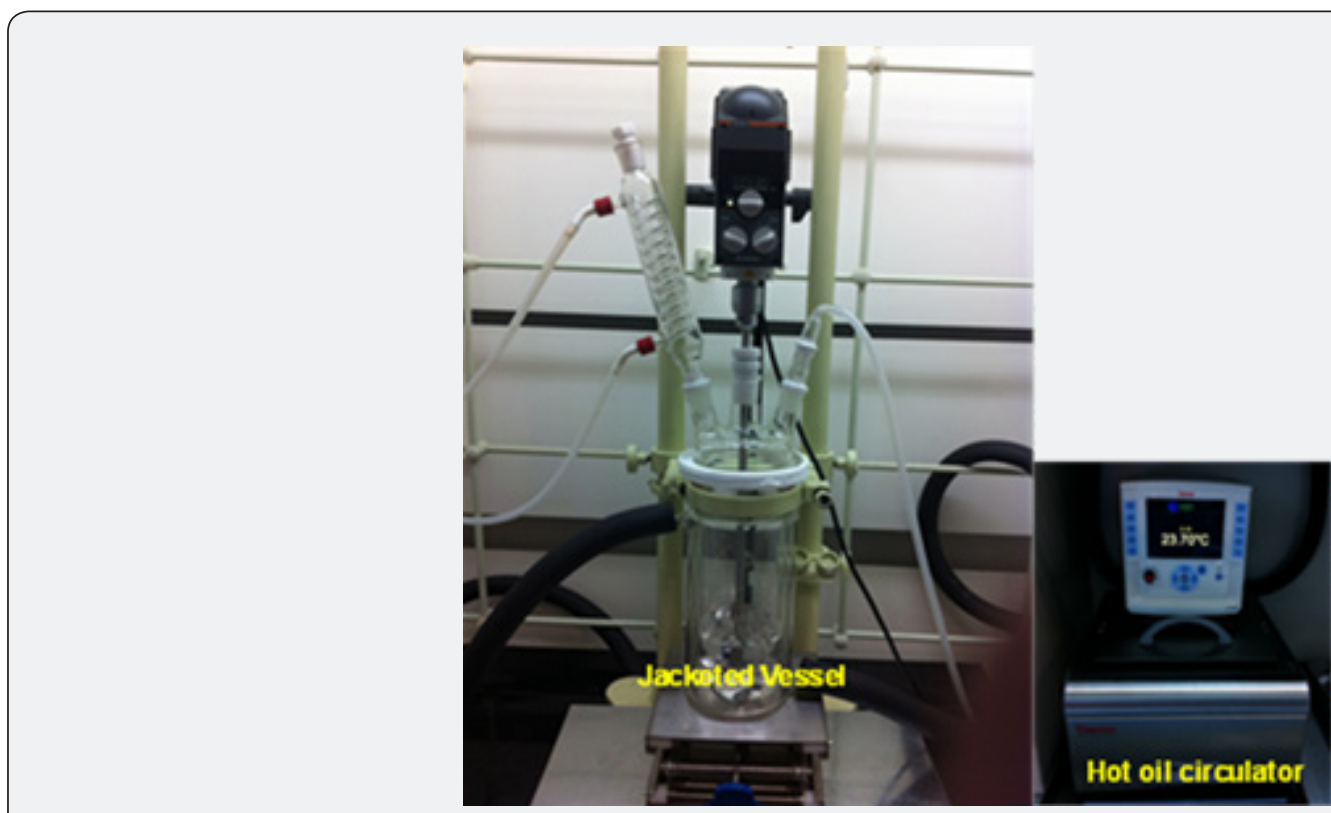

Figure S1: Lab scale glass reactor setup $(1 \mathrm{~kg})$.

\section{GPPS process and compounding}

To evaluate the final properties of the synthesized polystyrene and copolymers were processed in different steps as shown in the Figure 1.

\section{Results and Discussion}

\section{Different approaches to develop high heat GPPS}

Based on literature search and our expertise three different approaches had been identified to achieve the targeted properties (CTQ's). a. High molecular weight GPPS (Mw $\left.>300 \mathrm{~kg} \mathrm{~mol}^{-1}\right)$

b. Evaluation of cross linkers \& comonomers

\section{High molecular weight GPPS (Mw >300 kg mol-1)}

This approach is simple and straightforward; this has been achieved by optimizing reaction time and temperature of the synthesis process as shown in the Table 2. In general, polystyrene molecular weight (Mw) can grow up to $340-350 \mathrm{~kg} \mathrm{~mol}^{-1}$ in radical bulk polymerization technique at $3-3.5 \mathrm{~h}$ reaction time (pre-poly), but later decreased due to thermal degradation and 
long residential time. In order to achieve $\mathrm{Mw} \geq 300 \mathrm{~kg} \mathrm{~mol}^{-1}$, the polymerization was stopped after $4 \mathrm{~h}$ reaction time, with $\sim 80 \%$ conversion. At final stage high vacuum was applied for $10 \mathrm{~min}$ to remove 17-18 \% unreacted styrene, after double extrusion the final residual was $1500 \mathrm{ppm}$.

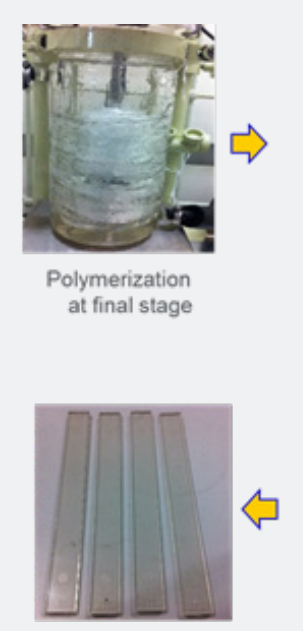

HDT specimens

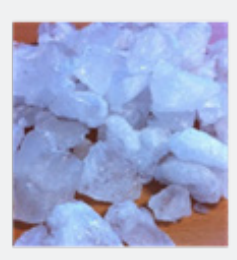

GPPS Lumps

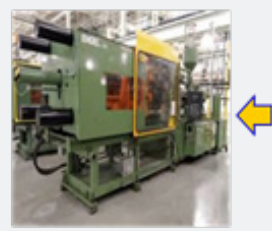

Injection molding machine

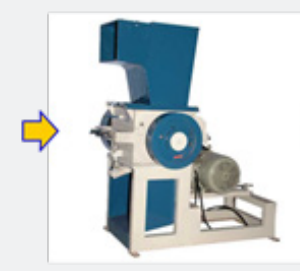

Pulverizer

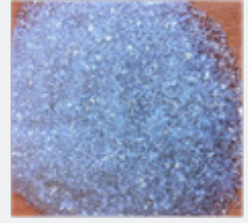

GPPS pellets

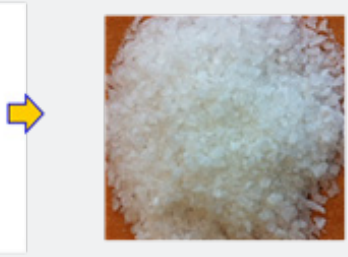

GPPS powder (3-4 mm)

§

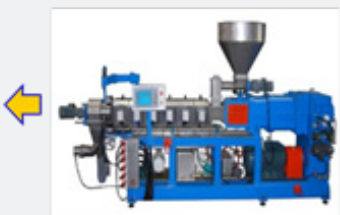

Extruder

Figure 1: GPPS process and compounding flow diagram.

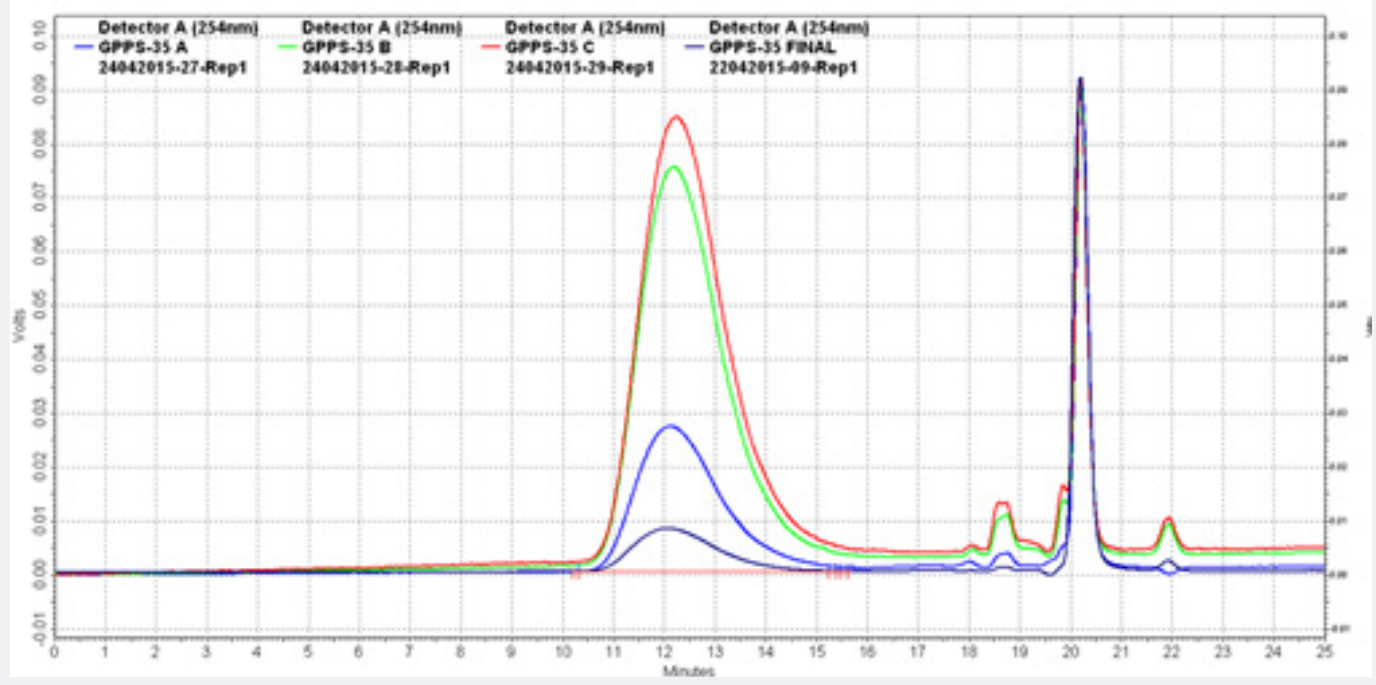

Figure 2: GPC chromatograms for high molecular weight GPPS at different stage of processing.

From Table 3, MFI data shows that as molecular weight increased the flow decreased, but HDT and VST increased by $2{ }^{\circ} \mathrm{C}$. Other mechanical properties like impact and tensile properties are better or equal to the baseline material PS160. Due to the low MFI, high molecular weight approach may have negative effect on processability and cycle time during molding. Figure 2, the GPC chromatograms shows that decreased molecular weight due to thermal degradation at different stages of processing.

\section{Evaluation of cross linkers \& comonomers}

Following cross linkers and comonomers were screened at different loading for high heat GPPS (Table 4) at $100 \mathrm{~g}$ scale. All the cross linkers were screened in the range of 50-500 ppm to avoid gelling in the reactor, whereas comonomers were tested in 1-5 wt. \% loading. DVB was shortlisted for scale-up in $1 \mathrm{~kg}$ scale and evaluated for thermal and mechanical properties as it showed 
better $\operatorname{Tg}\left(107{ }^{\circ} \mathrm{C}\right.$, when residual styrene $\left.\sim 100 \mathrm{ppm}\right)$. Moreover, it is commercially available in bulk quantities, FDA approved and reactivity is almost similar to the styrene monomer [6-7]. The same formulation was scaled up to $5 \mathrm{~kg}$ scale in batch reactor in similar reaction conditions. Tricyclo $\left(5.2 .1 .0^{2,6}\right)$ decane dimethanol diacrylate and $\mathrm{N}, \mathrm{N}$-Hexamethylenebis (methacrylamide) as crosslinkers did not show any improvement in $\mathrm{Tg}$ in the final polymer. MA showed best Tg among comonomers at 4-5 wt. \% loading and was scaled up to $1 \mathrm{~kg}$ in lab scale. DVB loading was optimized to $100 \mathrm{ppm}$, higher loading showed low MFI $(<3.0 \mathrm{~g} / 10$ Table 2: Process parameters for high molecular weight GPPS. min) because of high molecular weight and more crosslinking. Intermediate sample analysis showed that molecular weight increased up to $3^{\text {rd }}$ hour and then started decreasing (Figure 3). This is may be due to thermal degradation under dynamic reaction conditions. Styrene-DVB copolymer always gave broader PDI ( $\geq 3.0$ ) due to partial crosslinking or chain extension/branching, which leads to higher MFI. The chain extension was envisaged by lower slope/slower relaxation in the lower frequency region in rotational rheometer study as shown in Figure 4.

\begin{tabular}{|c|c|c|c|c|}
\hline & Pre-poly & Step 1 & Step 2 & After 2 extrusion and molding \\
\hline Rx time in h & 2.5 & 0.7 & 0.8 & -- \\
\hline Temp. in $^{\circ} \mathrm{C}$ & 128 & $142-143$ & $150-155$ & - \\
\hline Mw kg mol $^{-1}$ & 355 & 345 & 337 & $307-320$ \\
\hline Solid content \% & $40-42$ & $63-65$ & $78-80$ & - \\
\hline Viscosity Cps & 10000 & 80000 & -- & -- \\
\hline
\end{tabular}

Table 3: Thermal, flow and mechanical properties of high molecular weight GPPS.

\begin{tabular}{|c|c|c|c|}
\hline & PS160 (Baseline) & Example 1 & Example 2 \\
\hline Residual styrene & 500 & 1700 & 3200 \\
\hline Mw kg mol ${ }^{-1}$ & 273 & 320 & 2.2 \\
\hline PDI & 2.2 & $102(0.70)$ & $102(0.80)$ \\
\hline $\mathrm{HDT} /{ }^{\circ} \mathrm{C}$ & $100(0.30)$ & $3.1(0.06)$ & $3.2(0.14)$ \\
\hline $\mathrm{MFI} / 2.16 \mathrm{~kg} @ 230{ }^{\circ} \mathrm{C}$ & $3.9(0.03)$ & $106(0.10)$ & $106(0.12)$ \\
\hline Vicat $/ 1 \mathrm{~kg} / 50^{\circ} \mathrm{C}$ & $104(0.10)$ & $3.35(0.10)$ & $-\cdots$ \\
\hline E-modulus $(\mathrm{Gpa})$ & $3.16(0.10)$ & $53(0.10)$ & -- \\
\hline Tensile Strength $(\mathrm{Mpa})$ & $52(0.10)$ & $21.23(0.80)$ & -- \\
\hline Notched Izod impact $(\mathrm{J} / \mathrm{m})$ & $20.34(0.70)$ & & \\
\hline
\end{tabular}

Table 4: Tg, flow \& VST data for different crosslinkers/comonomers at different loading in $100 \mathrm{~g}$ scale.

\begin{tabular}{|c|c|c|c|c|c|c|c|}
\hline Cross-linker & Conc. & FDA & $\mathrm{Tg} /{ }^{\circ} \mathrm{C}$ & $\mathrm{Mw} / \mathrm{kg} \mathrm{mol}^{-1}$ & MFI & VST & Comments \\
\hline Divinylbenzene & $100 \mathrm{ppm}$ & $\sqrt{ }$ & 108 & 320 & $5-6$ & 107 & $\begin{array}{l}50-100 \text { ppm DVB push Mw } \\
\text { higher side without gelling }\end{array}$ \\
\hline $\begin{array}{l}\text { Tricyclo }\left(5.2 .1 .0^{2,6}\right) \text { decane } \\
\text { dimethanol diacrylate }\end{array}$ & $100 \mathrm{ppm}$ & $\mathrm{X}$ & 103 & 385 & -- & 100 & $\begin{array}{l}\text { Above } 500 \text { ppm Gel forma- } \\
\text { tion happens }\end{array}$ \\
\hline $\begin{array}{l}\text { N,N-Hexamethylenebis } \\
\text { (methacrylamide) }\end{array}$ & $100 \mathrm{ppm}$ & $\mathrm{X}$ & 101 & 350 & -- & 97 & $\begin{array}{l}\text { Above } 500 \text { ppm Gel forma- } \\
\text { tion happens }\end{array}$ \\
\hline \multicolumn{8}{|l|}{ Comonomers } \\
\hline Maleic anhydride & $1-5 \%$ & $\sqrt{ }$ & $104-107$ & $172-240$ & $12-8$ & $108-109$ & $\begin{array}{c}\text { Showed best Tg at } 4-5 \text { wt. \% } \\
\text { loading }\end{array}$ \\
\hline Alpha-methylstyrene & $1-5 \%$ & $\mathrm{X}$ & $100-103$ & $240-320$ & $4-3$ & $98-104$ & $\begin{array}{c}\text { No significant improvement } \\
\text { in Tg }\end{array}$ \\
\hline DCPD & $1-5 \%$ & $\mathrm{X}$ & $99-103$ & $230-300$ & $4-3$ & $97-104$ & $\begin{array}{l}\text { No significant improvement } \\
\text { in Tg }\end{array}$ \\
\hline
\end{tabular}


Solid content and viscosity at prepoly stage was almost similar to the homopolymer (Table 5). From Figure 7 it is very clear that residual styrene can affect Tg, that is higher the residual, lower the Tg, hence HDT/VST can also change accordingly (Table 6 ). It is required to maintain optimum level of $(<500 \mathrm{ppm}$, more preferably $<200 \mathrm{ppm}$ as in example 2) residual in the final polymer to hit HDT $>102{ }^{\circ} \mathrm{C}$ or VST $>106{ }^{\circ} \mathrm{C}$ as showed in table 6, example 2-4. The mechanical properties as if tensile strength \& impact were better than the baseline PS160 (Table 6). There is no change in the thermal stability of styrene-DVB copolymer at 100 ppm DVB loading in compared to baseline GPPS PS160 (Figure 2 SI). Comonomers were evaluated in 1-5wt.\% loading along with styrene, under similar reaction conditions as mentioned in the Table 2. Maleic anhydride (MA) showed HDT-102 ${ }^{\circ} \mathrm{C}$, and MFI 10-12 at 5 wt. \% loading, but imparts haziness to the final polymer and more brittle than baseline PS 160. MA cannot homopolymerize, however in the presence of styrene it always forms alternative copolymer. This is may be due to higher activity of MA (0.02 time higher than styrene) [8].
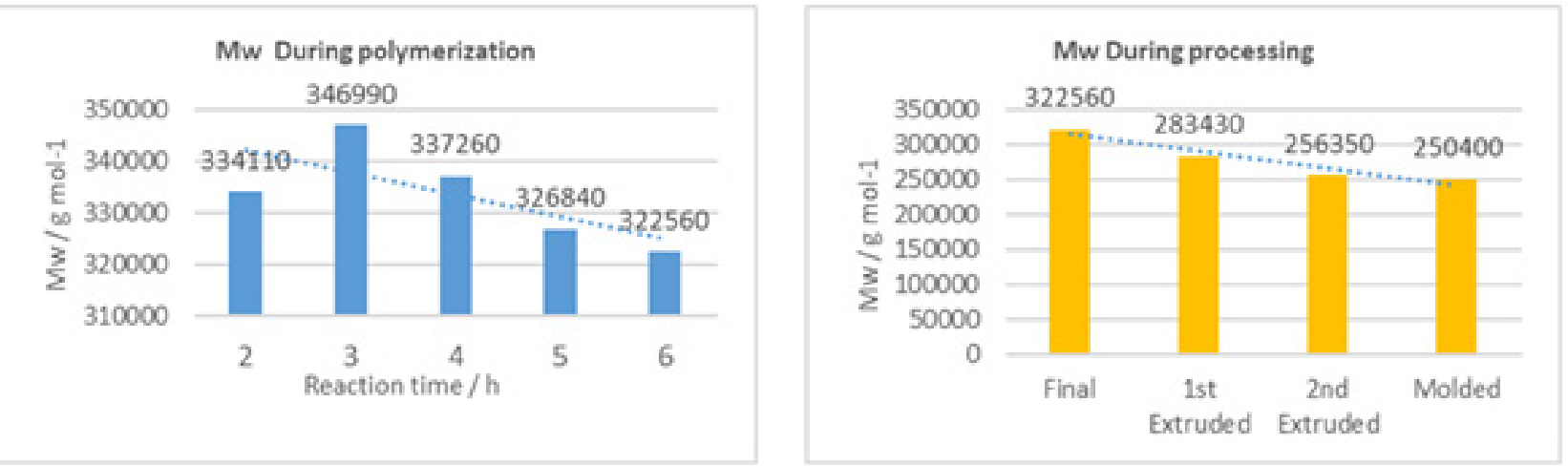

Figure 3: Molecular weight (Mw) variation of $100 \mathrm{ppm}$ DVB loaded GPPS at $1 \mathrm{~kg}$ scale.

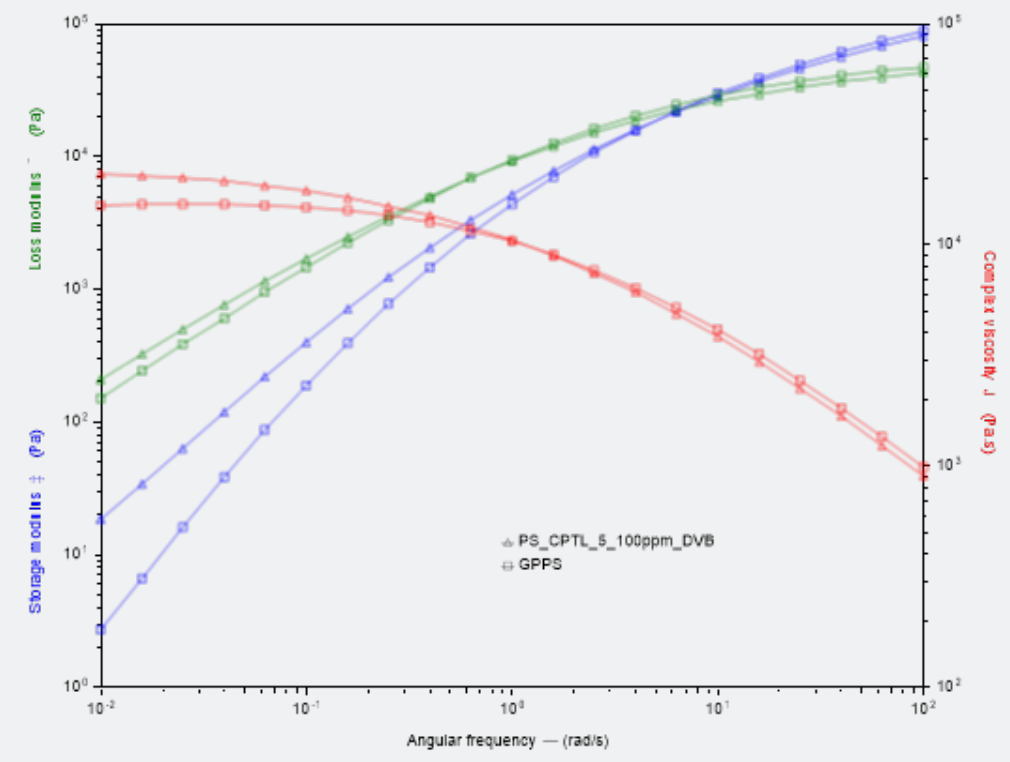

Figure 4: Storage modulus Vs frequency by rotational rheometry.

Since, we are restricted ourselves to MA content to 5 wt. \% maximum in the formulation, MA was added slowly over $1 \mathrm{~h}$ time in the prepoly stage and anticipated fair distribution throughout the chain. As MA content increased in the formulation the copolymer molecular weight decreased below critical molecular weight $\left(\sim 240 \mathrm{~kg} \mathrm{~mol}^{-1}\right)$ as showed in the Table $7 \&$ Figure 9. As 5 wt. \% loading showed $\mathrm{Tg} \sim 108^{\circ} \mathrm{C}$ (Figure 10), the same was scaled up to $1 \mathrm{~kg}$ in the lab reactor and evaluated for the mechanical 
and thermal properties. In styrene-MA copolymerization, the propagating chains were styrinic in nature because the maleic anhydride radicals undergo chain transfer reaction in this highly reactive system [9]. The styrene-MA system was highly exothermic compared to styrene homopolymerization and styrene-DVB system. This is because hydrogen abstraction from the maleic anhydride radical is $40 \mathrm{~kJ} /$ mol more exothermic than that of styrene radical. This finally leads to inferior mechanical properties compared to the baseline as shown in the Table 7. Other comonomers like alpha-methylstyrene and DCPD did not show considerable improvement in thermal or flow properties up to $5 \mathrm{wt}$ \% \% loading.

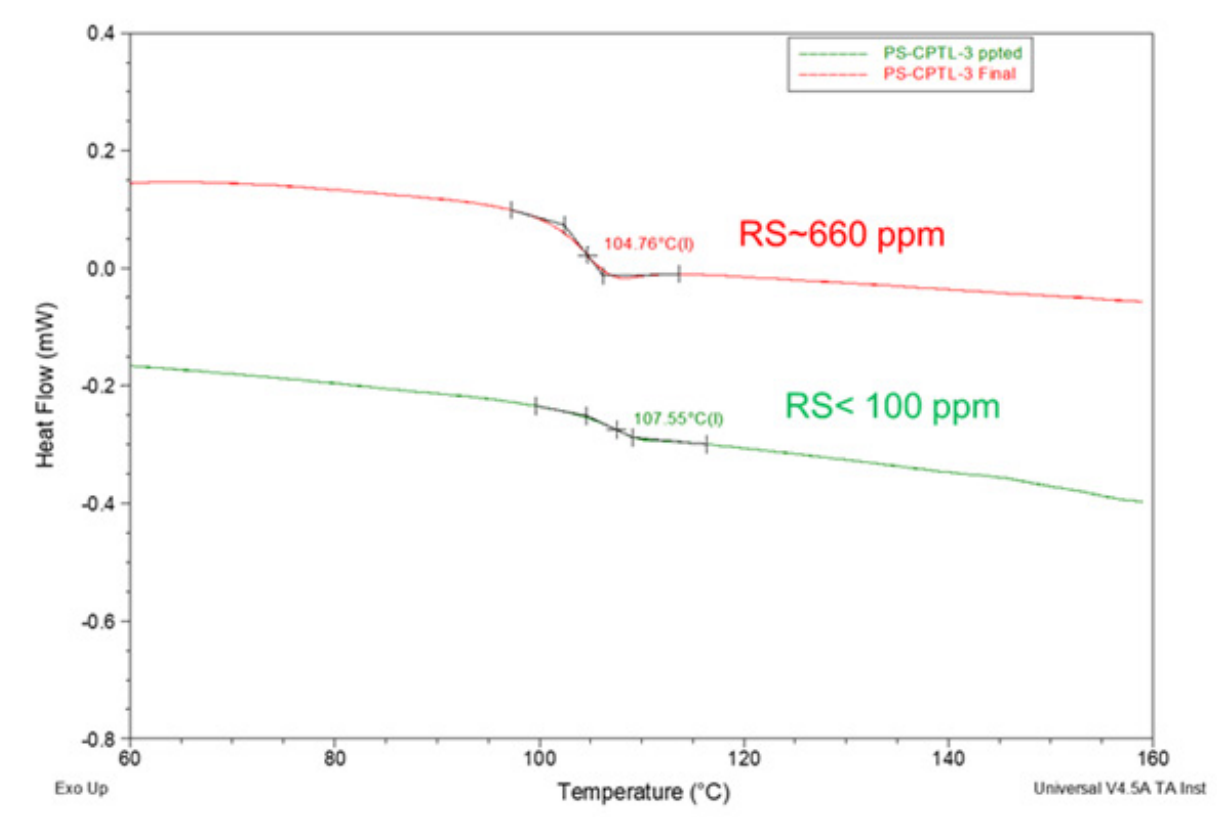

Figure 5: Effect of residual styrene on glass transition temperature $(\mathrm{Tg})$.

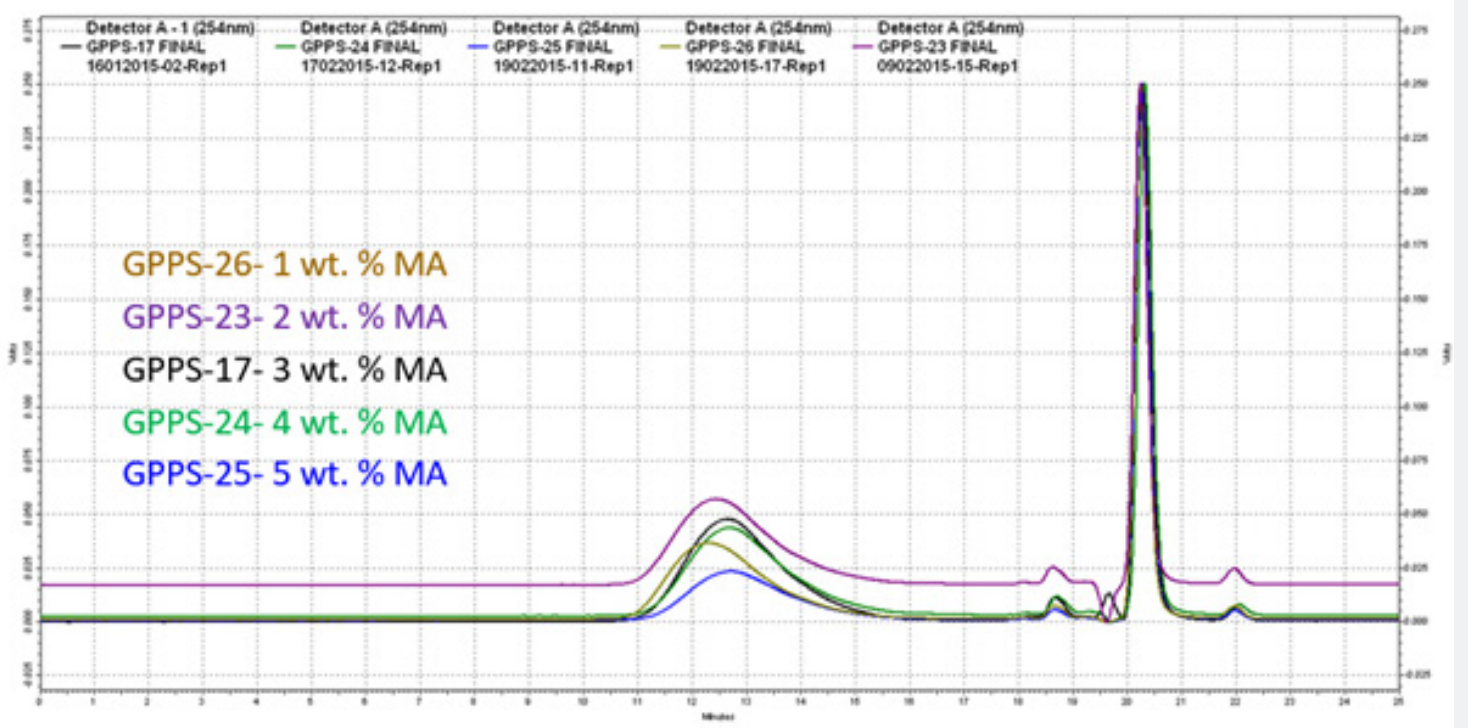

Figure 6: GPC chromatograms of 1-5 wt. \% MA loaded copolymers/GPPS. 
Academic Journal of Polymer science

Table 5: Mw, solid content \& viscosity data for 100 ppm DVB loading at different time intervals in lab scale up (1kg).

\begin{tabular}{|c|c|c|c|c|c|c|}
\hline & Pre-poly & Step 1 & Step 2 & Step 3 & Step 4 & After 2 extrusion and molding \\
\hline Rx time in h & 2.5 & 0.7 & 0.7 & 0.7 & $161-164$ & -- \\
\hline Temp. in ${ }^{\circ} \mathrm{C}$ & 128 & $142-143$ & $146-149$ & $153-156$ & -- \\
\hline Mw kg mol ${ }^{-1}$ & 334 & 346 & 337 & 326 & -- & -- \\
\hline Solid content \% & $38-40$ & $60-63$ & $75-80$ & $83-85$ & -- & - \\
\hline Viscosity Cps & 90000 & 70000 & -- & \\
\hline
\end{tabular}

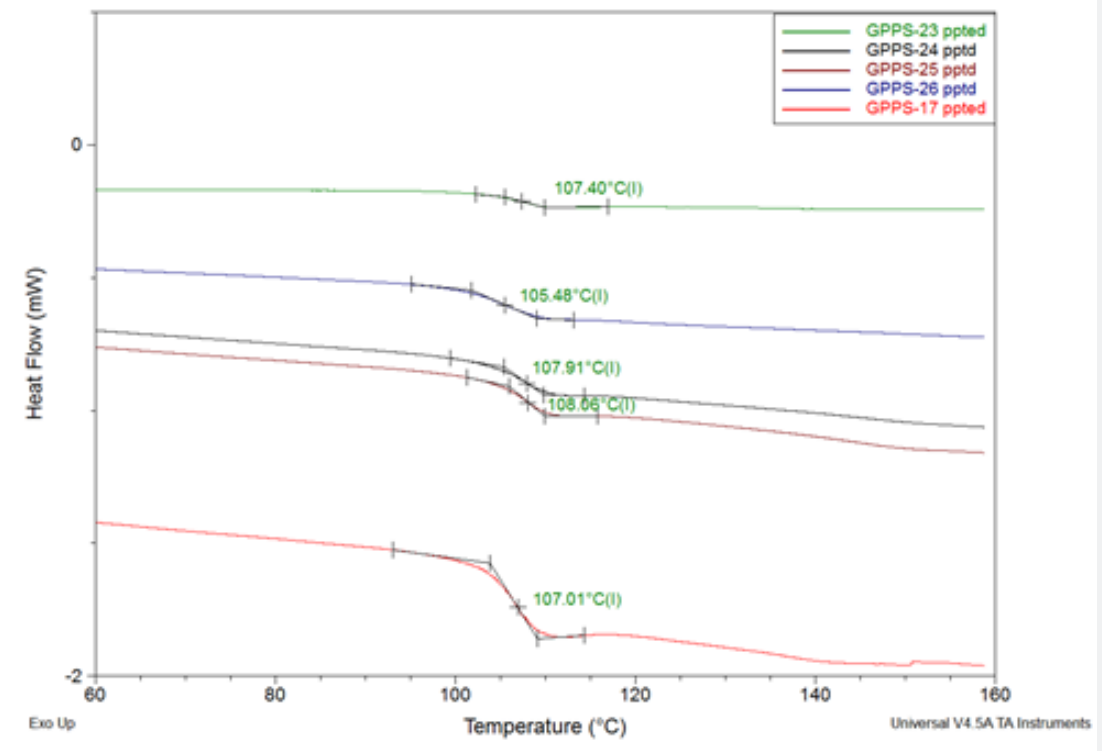

Figure 7: DSC chromatograms for 1-5 wt. \% MA loaded copolymer/GPPPS samples.

Table 6: Thermal, flow and mechanical properties of styrene-DVB copolymer GPPS at $1 \mathrm{~kg}$ scale.

\begin{tabular}{|c|c|c|c|c|c|}
\hline & PS 160 & Example 1 & Example 2 & Example 3 & Example 4 \\
\hline DVB (ppm) & 0 & 100 & 100 & 100 & 150 \\
\hline Residual styrene (ppm) & 500 & 662 & 200 & 1500 & 1200 \\
\hline $\mathrm{Mw}(\mathrm{x} 1000) / \mathrm{g} \mathrm{mol}^{-1}$ & 273 & 285 & 266 & 260 & 270 \\
\hline PDI & 2.2 & 2.9 & 2.7 & 3.1 & 3.2 \\
\hline $\mathrm{HDT} /{ }^{\circ} \mathrm{C}$ & $100(0.30)$ & $102(0.70)$ & $103(0.20)$ & $102(0.21)$ & $102(0.22)$ \\
\hline MFI / 2.16 kg @ $230^{\circ} \mathrm{C}$ & $3.9(0.03)$ & $5.5(0.02)$ & $6.5(0.05)$ & $7.0(0.08)$ & $6.0(0.10)$ \\
\hline Vicat $/ 1 \mathrm{~kg} / 50^{\circ} \mathrm{C}$ & $104(0.10)$ & $106(0.30)$ & $107(0.10)$ & $106(0.02)$ & $106(0.05)$ \\
\hline E-modulus (Gpa) & $3.16(0.10)$ & $3.13(0.11)$ & 3.35 & 3.2 & -- \\
\hline Tensile Strength (Mpa) & $52(0.10)$ & $52(1.30)$ & $51.04(0.39)$ & $51(0.38)$ & -- \\
\hline Notched Izod impact $(\mathrm{J} / \mathrm{m})$ & $20.34(0.70)$ & $20.09(0.81)$ & $19.2(0.30)$ & $20(0.28)$ & -- \\
\hline
\end{tabular}


Table 7: Variation of Mw \& $\mathrm{Tg}$ at different MA loading in $1 \mathrm{~kg}$ scale.

\begin{tabular}{|c|c|c|c|c|c|c|}
\hline Maleic anhydride / wt. \% & Mw / kg mol ${ }^{-1}$ & PDI & Tg & $\begin{array}{c}\text { Tensile strength } \\
\text { (MPa) }\end{array}$ & $\begin{array}{c}\text { Notched Izod } \\
\text { impact (J/m) }\end{array}$ & $\begin{array}{c}\text { Optical property of molded sam- } \\
\text { ples }\end{array}$ \\
\hline PS160 & 270 & 2.2 & 103 & 52.2 & 20.3 & Transparent \\
\hline 1 & 244 & 2.6 & 105 & 50.2 & 18.5 & Transparent \\
\hline 2 & 212 & 2.6 & 107 & 50.4 & 19.2 & Slightly Hazy \\
\hline 3 & 198 & 2.5 & 107 & 48.3 & 12.3 & Hazy \\
\hline 4 & 172 & 2.7 & 107 & 47.2 & 13 & Hazy \\
\hline 5 & 171 & 2.7 & 108 & 45.6 & 12,6 & Hazy \\
\hline
\end{tabular}

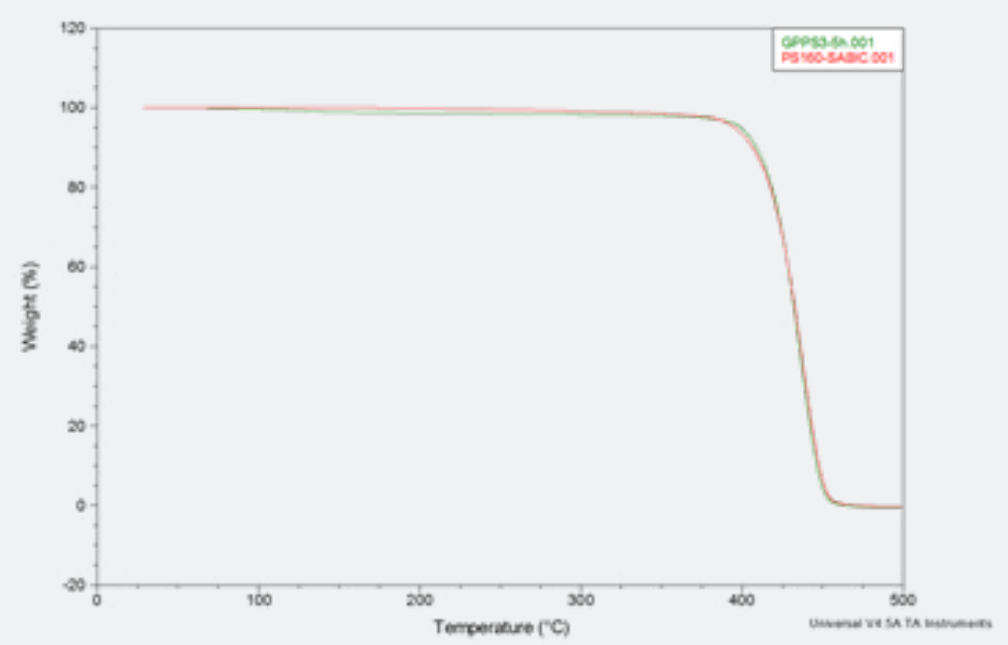

Figure 2: Thermogravimetric analysis of styrene-DVB copolymer and PS160.

\section{Conclusion}

Divinylbenzene (DVB) as a crossliker at $100 \mathrm{ppm}$ loading showed balance of thermal and flow properties as compared to baseline PS160. The controlled crosslinking of polystyrene chains by DVB play major role in broad distribution of molecular weight and hence better flow (MFI). There is an increment in the HDT/ VST by $2-3{ }^{\circ} \mathrm{C}$ and MFI from $3.3 \mathrm{~g} / 10 \mathrm{~min}$ to $7 \mathrm{~g} / 10 \mathrm{~min}$ without compromising any other properties of GPPS.

\section{Acknowledgment}

Funding was provided by SABIC

\section{References}

1. Wunsch JR (2000) Polystyrene-Synthesis, Production and Applications, Smithers Rapra Publishing.

2. Idemitsu. Engineering Plastics
3. Kelli S, Walter HJ, William AP, Houk KN et al. (2005) The mechanism of the self-initiated thermal polymerization of styrene. Theoretical solution for classing problem. J Am Chem Soc 127(4): 1265-1277.

4. Balwant Singh, Robort J (1994) Heat resistant resin composition comprising a polymer of $\mathrm{N}$-(substituted) maleimides and improved process for the preparation of said maleimides. US Patent 5,314,950.

5. Kemmish DJ (1995) High Performance Engineering Plastics, Smithers Rapra Publishing.

6. CFR - Code of Federal Regulations Title 21.

7. Satoshi Nakagawa, Shuji Yoshimi, Hayato Kihara (1998) Styrene base random copolymer and process for the producing the same. US Patent $5,854,366$.

8. Inderjeet (2012) Synthesis and characterization of acrylic acid grafted sytene-maleicanhydride copolymer, Der Chemica Sinica 3: 343-358.

9. Gemma C, Robert D, Ching Y, Michelle LC, Johan Ah et al. (2012) Endfunctional styrene-maleicanhydride copolymers via catalytic chain transfer polymerization, Macromolecules 45: 5923-5933. 
(C) Commons Attribution 4.0 License

BY DOI: 10.19080/AJOP.2021.04.555650

\section{Your next submission with Juniper Publishers will reach you the below assets}

- Quality Editorial service

- Swift Peer Review

- Reprints availability

- E-prints Service

- Manuscript Podcast for convenient understanding

- Global attainment for your research

- Manuscript accessibility in different formats

( Pdf, E-pub, Full Text, Audio)

- Unceasing customer service

Track the below URL for one-step submission https://juniperpublishers.com/online-submission.php 